U.S. DEPARTMENT OF THE INTERIOR

U.S. GEOLOGICAL SURVEY

\title{
GEOLOGIC MAP AND STRUCTURE SECTIONS OF THE SIERRA JUÁREZ, CHIHUAHUA, MEXICO
}

By Harald Drewes and Russ Dyer 